\title{
The research centre for education and labour market
}

Citation for published version (APA):

Heijke, J. A. M. (1986). The research centre for education and labour market. Researchcentrum voor Onderwijs en Arbeidsmarkt, Faculteit der Economische Wetenschappen. ROA Reports No. 1E https://doi.org/10.26481/umarep.198601E

Document status and date:

Published: 01/01/1986

DOI:

10.26481/umarep.198601E

Document Version:

Publisher's PDF, also known as Version of record

\section{Please check the document version of this publication:}

- A submitted manuscript is the version of the article upon submission and before peer-review. There can be important differences between the submitted version and the official published version of record.

People interested in the research are advised to contact the author for the final version of the publication, or visit the DOI to the publisher's website.

- The final author version and the galley proof are versions of the publication after peer review.

- The final published version features the final layout of the paper including the volume, issue and page numbers.

Link to publication

\footnotetext{
General rights rights.

- You may freely distribute the URL identifying the publication in the public portal. please follow below link for the End User Agreement:

www.umlib.nl/taverne-license

Take down policy

If you believe that this document breaches copyright please contact us at:

repository@maastrichtuniversity.nl

providing details and we will investigate your claim.
}

Copyright and moral rights for the publications made accessible in the public portal are retained by the authors and/or other copyright owners and it is a condition of accessing publications that users recognise and abide by the legal requirements associated with these

- Users may download and print one copy of any publication from the public portal for the purpose of private study or research.

- You may not further distribute the material or use it for any profit-making activity or commercial gain

If the publication is distributed under the terms of Article $25 \mathrm{fa}$ of the Dutch Copyright Act, indicated by the "Taverne" license above, 
THE RESEARCH CENTRE FOR EDUCATION AND LABOUR MARKET

$$
\text { ROA-R-1986/1/E }
$$

J.A.M. Heijke

RESEARCH CENTRE FOR EDUCATION AND LABOUR MARKET

Faculty of Economics and Business Administration University of Limburg

Maastricht, September 1986 
TABLE OF CONTENTS

Page

1. Short history

1

2. Tentative delimitation of the work area

4

3. Tasks

6

4. The research programme 9

5. Some organisational aspects 


\section{SHORT HISTORY}

In the course of time, scientific research has shown a varying interest in the mutual adjustment of education and the labour market. In the 1960s, economic questions related to the contribution of education to economic growth and to the return on education were in the centre of interest. Afterwards, attention shifted to the more sociologically flavoured problems of how to taylor education to professional practices and how to improve the quality of work in the sense of adapting it to human proportions and capabilities, and how to achieve a more equal income distribution and overcome social inequality.

When, in the 1980s, new impulses were looked for to restore the economic potential, which had been seriously weakened during the recession, the contribution of education to economic growth once more came into the limelight. The prospects of new economic growth also rekindled the debate about the compatibility of schools and practice, which had apparently died down with the drop in employment. The objective of humanising work by raising its quality seems to have been replaced with that of a more efficient organisation, in the economic sense, through social innovation. Emphasis now being on stimulating the economic potential, the problems of social and income inequality have been pushed into the background.

Currently, growing attention is given to the consequences which technological progress in automation, informatics and biotechnics has for education and for the labour market. Educational choices and especially weighing students' future prospects on the labour market, have also become matters of keen interest. Although education aims at more than just to prepare young people for professional life, schemes are being developed and tested to restructure (vocational) education, tayloring it more to the requirements and prospects of the labour market.

Aware of current developments, the Ministry of Education and Sciences proposed an Education and Labour-Market Project to be carried out by the Faculty of Economics and Business Administration of the University of Limburg (RL), and requested Dr. J.A.M. Heijke to gather some relevant facts and inform the Economics Faculty as to the possible plan- 
ning of such a project in such a way as to comply with the need felt by the Ministry of Education and Sciences and at the same time fit in the organisation of scientific research of the RL Economics Faculty.

Dr. Heijke was asked to orient himself at home and abroad, to list interesting foreign examples, and then work out a project suiting the demands.

The assignment was given in May 1985; the information report ${ }^{1)}$ was completed in November of that year. The main conclusion of the report was that there was an obvious need for an agency permanently engaged in analysing, (quantitative) forecasting, and establishing the relations between developments on the educational and labour markets. The final commission of the project, in June 1986, in accordance with that conclusion stipulated that the Education and Labour-Market Project was to yield at any rate an information system capable of reflecting the developments on the labour market and expressing the educational demands deriving from them. The system to be developed was to be a suitable instrument for the guidance of students of secondary schools and universities as to their choice of study subjects and professions. The assignment stretches over the period from September 1, 1986, to August 31, 1991.

Responding to the conclusion of the information report, the Economics Faculty of RL decided to establish a centre for the investigation of educational and labour-market problems: the Research Centre for Education and Labour Market (in Dutch: Researchcentrum voor Onderwijs en Arbeidsmarkt - ROA). It will be incorporated in LIBER, the research institute of the RL Economics Faculty. The research themes which the Centre proposes to treat are those mentioned in the information report; they will be enumerated below. To become self-supporting, the centre will set out to acquire research commissions in line with these themes. The centre's first major commission is the Education and Labour-Market Project, conferred upon it by the Ministry of Education and Sciences. The next sections will deal in succession with the tentative delimitation of the research centre's work area, its tasks, the research

1) J.A.M. Heijke, Het Projet Onderwijs en Arbeidsmarkt van de Rijksuniversiteit Limburg - informatierapport -, Krimpen aan den IJssel, November 1986. 
topics chosen, and some organisational aspects. The description is largely borrowed from the information report.

EDULABOUR, EV13 


\section{TENTATIVE DELIMITATION OF THE WORK AREA}

Research into the problems of education and labour market can roughly be divided into the investigation of, first, the qualitative aspect, and second, the quantitative aspect of the relation between education and labour market; there is some overlap between the two. How to match the attitude, knowledge and skills transferred by education to the requirements of future jobs - what is commonly called the match between educational programme and professional practice - is the qualitative aspect. How to match the supply of persons possessing certain types of knowledge and certain skills to the demand for such persons is the quantitative aspect.

In the Netherlands, the problems of qualitative matching are studied with relative intensity, for instance by development institutes: Stichting voor de Leerplanontwikkeling (SLO; Foundation for Curriculum Development) in Enschede, Pedagogisch Centrum Beroepsonderwijs Bedrijfsleven (PCBB; Pedagogic Centre for Professional Training for Business) in Bois-le-Duc; and the research institutes of the Technical University of Twente (Enschede) and the Nymegen Catholic University. The study of the quantitative problems is clearly underdeveloped by comparison. The Central Planning Office (CPB) analyses educational flows but without relating them explicitly to the labour market. The Socio-Cultural Planning Office (SCP) was at one time studying the development of the educational structure of employment in the quaternary sector. In a recent report, the Netherlands Economic Institute presents medium-term forecasts of the development of the labour market by profession and education, based on a practical approach and a rough division of professions and types of education $^{2)}$. The information report justly concludes that there is room for an agency whose permanent concern are the (quantitative) developments on the educational and labour markets, and whose analyses and forecasts:

i) point out the relations between the two developments;

2) Nederlands Economisch Instituut, Een verkenning van de arbeidsmarkt naar beroep en opleiding tot 1990, OSA working document $\mathrm{Nr} W 17$, January 1986. 
(ii) cover in principle all types of education and the entire labour market;

(iii) are differentiated to ensure optimum compatibility with the more qualitative aspects of the relation between education and labour market;

(iv) give as much attention to theoretical foundations of applied research as to its practical execution.

Those taking part in the interviews mostly conceded the importance of medium-term labour-market forecasts differentiated by profession or occupation and schooling, but also pointed at the problems involved. They pointed out that current models lack forecasting power and have a weak behavioural foundation, and emphasised that the labour market is more flexible than is suggested by the usual division into submarkets. For those and other reasons the discussion partners showed themselves loth to base the planning of educational services directly on forecasting outcomes. The present uncertainty is circumvented in two ways. First, by structuring (vocational) education such as to permit fast adjustment to new business requirements, and second, by teaching such knowledge and skills as will enable students to respond instantly to new developments in their later professions. Closer co-operation with business enterprise, development of on-the-job training schemes and the apprenticeship system, and the creation of reschooling opportunities, are among the targets envisaged. Admittedly, the reticence to plan educational services on the basis of forecasts is sometimes inspired by established interests.

The interviewed persons take a more positive view of the labourmarket forecasts as guidelines for study choices and job changes; they hold no high opinion of the guidance services now available. The information report has made it clear that there is an urgent need for information about future chances on the labour market, the content of occupations, proliferation prospects, career perspectives, and remunerations. 


\section{TASKS}

The exploratory interviews and the project's association with the RL Economics Faculty have inspired a specific orientation of the activities of the Research Centre for Education and Labour Market (ROA). The analysis of the problems involved in the adjustment of education to the labour market, and the analysis and forecasting of the developments on the educational and labour markets, and the relation between them, have therefore been chosen as the centre's primary task. Carrying it out, the centre will be able to satisfy the apparent need for information about developments on the labour market bearing on education, build up adequate scientific authority, and extend and deepen theoretical knowledge. The accent thus being on analysing and forecasting, to collect and diffuse information about the (quantitative) development on the labour market and in education could be regarded as the centre's secondary task within the tentative limits of its work area.

All other activities of the centre will derive from the primary task and the corresponding delimitation of the work area, that is to say, they will be executed if, and as far as, they are relevant to, or spring from, the project's primary objective: to make analyses and draw up forecasts. Thus, curriculum development would be excluded from the centre's research area; fortunately, some well qualified research and development institutes of international fame, are already active in that field. That the centre's research should be as much as possible in line with development activities, is obvious.

Nor would the centre concern itself with the optimum institutional structure of (vocational) education or with the infrastructure needed to consolidate the coherence of research, development work, and policy. What institutional and infrastructural changes would be desirable, is the concern of policy makers and interest groups. Nevertheless, the centre could, within its range of action, provide information to help make the most rational choices, and point out what would be the consequences of policy decisions for the adjustment of education and labour market.

Inventory of similar research carried on in the Netherlands and abroad, is part of the centre's primary task. The centre's own research activities and the inventory of activities elsewhere must provide the basis for the collection and diffusion of information. The information 
should be arranged to allow the centre to supply, whether or not on request, a more or less complete and differentiated picture of possible future medium- and long-term developments with regard to (the mutual adjustment) of education and the labour market. To that end, a network of national and international contacts for the collection of documentation and information must be established. Besides, potential groups of users could be informed of the information available to them by publications taylored to their sphere of interest.

Whether the centre could successfully fulfil a co-ordinating task is questionable. For one thing, other institutions are not likely to respond to an invitation to fill certain gaps in research and development unless they find it profitable. As far as professional interests are at stake, the centre will have to acquire a scientific standing high enough to convince others. To that end the centre's research work must find national and international recognition.

Besides the professional interest, financial interests are at stake. To provide the elements found missing from research and development work, institutions must have adequate financial means, which implies that the centre must have financial resources at its disposal. Coordination in the form of carrying out a programme of research and development on the basis of a budget, would mean an overlap with the svo (Foundation for Research into Education) and OSA (Organisation for Strategic Labour-market Research) programmes.

The co-ordination and signalling task envisaged will therefore be confined to some modest initiatives, such as:

(i) to report on important developments in the realms of education and labour market;

(ii) to organise symposias and other meetings to propose and discuss questions concerning the mutual adjustment of education and labour market;

(iii) To conduct the centre's activities keeping in mind the work of other institutions in the same work area, for instance as research institutes like the SCP and the CPB, and bodies engaged in co-ordination and data collection, such as the SVO, the OSA and the CBS (Central Bureau of Statistics). 
To give policy advice is another task of the centre. The desirability and possibility of policy measures cannot always be measured by objective research outcomes and scientific knowledge. Institutional and infrastructural matters, in particular, often demand subjective appraisal and the weighing of interests. The centre could be helpful, however, by

(i) pointing out the developments which come in its own territory and are relevant to policy decisions;

(ii) transforming policy questions with respect to the adjustment of education and labour market into investigable problems, and examining the latter;

(iii) examining and evaluating (possible and probable) consequences of present and future policy measures to do with the adjustment of education and labour market;

(iv) presenting research results in a form accessible to policy makers. 


\section{THE RESEARCH PROGRAMME}

The first task of the Research Centre for Education and Labour Market (ROA) will be to programme its future activities and their spread in time, setting priorities within the work area delimitated, and taking account of the research commissions obtained, and the budget and manpower at its disposal. The programme will be updated periodically to incorporate current developments and new insights.

The work area of the centre has been determined in view of the terms of reference for the exploratory investigation, the interviews held with informants and the overall plan of the scientific research of the RL Economics Faculty, after consultation with the Ministry of Education and Sciences. The short description following below is mostly taken from the informative report.

Research at the RL Economics Faculty falls apart into three areas of attention, which also determine the planning of teaching. The areas of attention are: the economics of technological advance, the economics of labour, and the economics of government behaviour and the public sector. These themes, or areas of attention, correspond to the need, apparent from the discussions, for more quantitative information about developments on the labour market in relation to education, and, vice versa, the developments in education in relation to the labour market, both preferably in a medium- to long-term view. Moreover, these themes are in line with some other wishes expressed by the informants with respect to the relation between education and labour market, the economic aspects of (vocational) education, and the policy pursued in those areas.

Urgent as the need for explorations into the future may be, many informants were doubtful as to the predictability of the developments in question. That attitude has led, for one thing, to some reticence as to the use of forecasts for planning school capacities, and for another, to attempts at structuring education in such a way as to permit optimum response to unforeseen evolutions. Nevertheless, there is a (recurrent) need for a clearer view of future developments, so as to:

(i) achieve a rational capacity planning in education;

(ii) inform potential students and graduates of their (future) prospects on the labour market; 
(iii) adjust the content of teaching to future demands and prospects;

(iv) structure economic potential such as to permit optimum profit from the investments in the population's knowledge and ability.

In view of the prevailing doubts, the programme needs to pay special attention to fundamental research; a practical suggestion is to repeat the exploratory work at regular intervals.

In concrete terms, the intention is to include the following themes in the research programme:

1. The evolution of employment by sector, profession (or occupational category), and qualifications required, as determined by economic growth, the development of process and product technologies, and changes in the organisation of production units.

2. The interest, inflow, throughput and outflow of students at formal schools and training courses, and participants in apprentice schemes as governed by demographic development, school performance, social background, and expectations as to future chances on the labour market and other factors.

3. Discrepancies between supply and demand on the labour market, by level and type of qualification, as well as the nature, working, and effectiveness of the co-ordination mechanisms which may bring supply and demand on the various submarkets closer together.

4. The careers of persons with a given (professional) education in relation to the requirements made in successive jobs, and the way in which these requirements are satisfied.

5. The development patterns through time of certain professions and occupational categories in relation to the utilisation of the knowledge and skills of those fulfilling these professions and occupations.

6. The influence of (professional) education and the qualifications it gives, on wages, productivity, and the acceptance or abandonment of jobs.

7. The planning, costs and effectiveness of facilities and capacities of formal professional education and (on-the-job) training courses. 
8. The development of adequate data systems and sources permitting research into the abovementioned themes.

9. The development of adequate classification systems, so that different bodies of information yielded by the investigations can be linked among themselves and connected with the organisation of (professional) education and the curricula developed for it.

As the programme gets carried out, special attention will be given to the definition of concepts, the differentiation of data, and the form in which the information acquired will be published. The goal is to provide as much as possible the information required by educational institutions, agencies engaged in labour-market programmes and in developing curricula, as well as by business enterprise and the population at large.

The research themes enumerated above will not all be taken up at once. The knowledge and research instruments required needs to be built up gradually. Moreover, the content of the commission given by the Ministry of Education and Sciences - the Education and Labour-Market Projet -, which stretches over several years, compels the centre to make a choice. For the time being, priority is given to the themes 1 through 3 , 8, and 9. Theme 1 (the structure of employment development, the very theme of the Education and Labour-Market Project) will be given the highest priority, while the themes 8 and 9 will be treated only as far as necessary for the adequate execution of themes 1 through 3.

To establish the programme of activities and research with respect to the above themes, the following elements must be defined.

(i) The category of users to be addressed (education authorities, labour-market authorities, business enterprise, curriculum- development institutions, population).

(ii) The nature of the (quantitative) data which these users need (quantities, indices, future periods, periodicity of the information).

(iii) The form and format in which to prepare the information for the various user categories (easy-access report, scientific account, article, booklet, tables). 
(iv) The data files to be employed (in particular information on profession and education).

(v) The differentiation of the data to meet various requirements, and the classification systems to achieve the differentiation and link the various data files together.

(vi) The models, systems, and other analytic instruments by which to generate the required data.

(vii) The agencies with which to co-operate to convey the data to the final users, through existing or new forms of publication.

(viii) The researchers and institutions which on account of their specific expertise and experience and the research instruments at their disposal can carry out certain parts of the research programme.

(ix) Co-ordinating activities (meetings to discuss certain aspects of the programme).

(x) The budget and time chart of the complete programme (the centre's own research activity, investigations to be contracted out, the co-ordinating activities, the purchase and use of data files, the purchase and management of documents, publishing activities).

In concrete terms, the programme may involve the periodic exploration, say every other year, of future developments on the labour market and in education and the relations between them. For the time being, medium-term evolutions are thought of. In the intermediary periods, progress reports and publications may be issued at regular intervals about more specific subjects which in the medium term are likely to become important for the relation between education and the labour market.

Besides research, the centre will undertake outward-oriented informative and co-ordinating actions, such as the organisation of symposia and other meetings where matters concerning the mutual adjustment of education and the labour market will be brought up and discussed.

The commission of the Ministry of Education and Sciences requires that the Education and Labour-Market Project produce at any rate an information system capable of visualising (future) developments on the labour market and specifying the corresponding educational requirements. 
The system must be suitable to guide students of secondary schools and universities as to their choice of study subject and profession.

For the purpose of educational and professional guidance, the government envisages the establishment of automated (information) systems. The most important project in that context is (pilot) project ISEE, carried out by Klijnveld Bosboom Hegener by commission of the Interedepartmental Steering Group for the Guidance of Educational and Professional Choices (ISBV), and financed by the Ministry of Social Affairs and Employment (SZW). Some other, partly associated projects are: CHOICES (SLO), IBO/MISTRAL (DG Arbvo of the Ministry of Social Affairs and Employment), PAIS, and MIDAS. Such systems tend to suffer from the lack of adequate labour-market data, a lack which the Education and Labour-Market Project is intended to fill. That ought to provide a basis for fertile co-operation between the centre and the automation projects just mentioned. The I-SEE project, which is intended to develop into a new policy instrument, could perhaps be contributed to by the Research Centre; the instrument, which would have a a broad supporting basis (Ministries of Education and Sciences, Social Affairs and Employment, and Economic Affairs, as well as educational institutions), would fill an urgent need. 


\section{SOME ORGANISATIONAL ASPECTS}

The activities envisaged are of two kinds:

a. fundamental research to support the empirical investigations mentioned under $b$. The fundamental research will be concerned with developing and testing (new) theoretical insights, and constructing models and other analytical instruments. This kind of research puts scientific significance first, and involves rather high risks;

b. applied (empirical) research, carried out by commission of third parties and supposed to yield practical results. This kind of research must directly lead to publications as envisaged in the terms of reference and to be included in the programme. In the same category come the establishment and management of the data files and classification systems required, informative and co-ordinating activities, and investigations contracted out to other bodies.

For efficient execution of the tasks of the Research Centre for Education and Labour Market (ROA), the fundamental research mentioned under $a$ and the applied research under $b$ must be compatible, and carried out within one single programme. Naturally, commissioned investigations can only be tentatively programmed, because the nature, size and time of new commissions cannot be planned beforehand.

Developing the research programme will be a coherent research effort in the realm of educational and labour-market evolution; the programme will be all the more effective because it will be drawn up and carried out by the Research Centre for Education and Labour Market, a set-up which gives it a clear profile both towards the Faculty and towards the outside world, and emphasises its permanent character.

The research centre will be manned by a number of full- or parttime associates, paid from the commissions to be obtained. Dr. J.A.M. Heijke has been found willing to direct the centre.

To ensure the adequate co-ordination of the research and the efficient utilisation of the services available, the centre will be incorporated in LIBER, the research institute of the RL Economics Faculty. The primary objective of the Research Centre for Education and Labour Market is to contribute to the external and internal profilation 
of a coherent programme of research, and to carry out some outward-oriented, informative and co-ordinating activities. Its incorporation in the Faculty's research institute concerns in particular the organisation of the centre and the utilisation of services; towards the outer world the centre will act independently.

The programme of activities and research will be updated every year. While the first programme is being developed, attempts will be made to get other commissioners besides the Ministry of Education and Sciences interested in the centre's work.

Two types of supervision are envisaged for the establishment and execution of the programme:

(i) Annual submission of the programme and the methods applied to the judgment of scientific experts.

(ii) Regular consultation with guidance committees from the government and other commissioners regarding the activities and plans they are financing. 